\title{
Current asset management of military construction joint stock corporations
}

\author{
Hoang Thi Khanh $\operatorname{Van}^{1}$, Nguyen Quoc Toan ${ }^{2, *}$, and Le Hoang Long ${ }^{1}$ \\ ${ }^{1}$ Le Quy Don Technical University, Hanoi, Vietnam \\ ${ }^{2}$ Faculty of Construction Economics and Management, National University of Civil Engineering, \\ Hanoi, Vietnam
}

\begin{abstract}
The restructuring of Construction Enterprises in Military since 2000 by equitization and divestment is considered as a part of the reforming of State Owned Enterprises (SOEs) that is a crucial pillar of the Government's structural reform toward a market-oriented economy under deeper international economic integration in Vietnam. The outcome of analysis indicates that reform of Military Construction Enterprises has made progress that has resulted in a significant expansion in the production capacity, improvement of expertise and management ability, and enhancement of competitiveness. On the other hand, the reforming of Military Construction Enterprises has been confronted with a range of issues such as financial management, improving labor productivity or innovating technology. The article focuses on the status of current asset management, which plays a crucial role in the financial management of Military Construction Joint Stock Corporations, then highlights significant achievements, and points out shortcomings to be eliminated in order to restructure Military Construction Joint Stock Corporations in the coming time.
\end{abstract}

\section{Introduction}

The reform of State Owned Enterprises (SOEs) is a crucial pillar of the Government's structural reform toward a market-oriented economy under deeper international economic integration in Vietnam 1. The restructuring of Construction Enterprises in Military since 2000 by equitization and divestment is considered as a part of the reforming plan 234 .

The outcome of analysis indicates that reform of Military Construction Enterprises has made progress that has resulted in a significant expansion in the production capacity, improvement of expertise and management ability, and enhancement of competitiveness. On the other hand, the reforming of Military Construction Enterprises has been confronted with a range of issues such as financial management, improving labor productivity or innovating technology. The article focuses on the status of current asset management, which plays a crucial role in the financial management of Military Construction Joint Stock Corporations, then highlights significant achievements, and points out shortcomings to be eliminated in order to restructure Military Construction Joint Stock Corporations in the coming time.

\footnotetext{
*Corresponding author: toannq@nuce.edu.vn
} 
A number of research studies have been carried out regarding financial management of construction enterprises, including current asset management: Eugene F. Brigham, Joel F. Houston (2009) 5 and Chandra, Prasanna (2011) 6. The research works of these authors are quite massive, but suitable for industrial production enterprises in general, not associated with the characteristics of construction enterprises. Luu Thi Thu Ha (2015) 7 discussed the financial management of state-owned enterprises, particularly Coal - Mineral Industries Group, with different features compared to construction ones. Besides, Pham Thi Van Huyen 8 mentioned construction enterprises that are equitized and listed on stock exchange. However, there has yet any thorough research on financial management, particularly the current asset management of Military Construction Joint Stock Corporations given that the Ministry of Defense is implementing tough measures to restructure military construction enterprises to enhance their operational efficiency 91011 in line with the world economic integration and against the State capital loss.

It can be pointed out that current assets account for a large proportion in the total assets of most Military Construction Joint Stock Corporations in Vietnam. Therefore, the management of current assets plays an important role in financial management of Military Construction Joint Stock Corporations. The article evaluates the status of current asset management of these enterprises during 2015-2019, and then provides some recommendations to improve enterprises' current asset management in accordance to the policies of restructuring military enterprises being implemented by the State and Ministry of Defense.

\section{The status of current asset management of military construction joint stock corporations}

\subsection{Achievements in current asset management and causes}

\section{a) Firstly, the selection of investment asset is quite reasonable}

Unlike other manufacturing enterprises, military construction enterprises focus on current assets rather than non-current ones. Table 1 shows the ratio of current assets to total assets of Military Construction Joint Stock Corporations according to owner's equity. It can be seen from the table that Military Construction Joint Stock Corporations have pretty high ratios of current assets to total assets with an average of approximately over $80 \%$, which remains quite stable over the years.

Table 1. Current asset - total asset ratio of Military Construction Joint Stock Corporations during 2015-2019

\begin{tabular}{|c|c|c|c|}
\hline \multirow{2}{*}{ Year } & \multicolumn{3}{|c|}{$\begin{array}{c}\text { Current asset - total asset of Military Construction Joint Stock Corporations } \\
\text { according to owner's equity scale (\%) }\end{array}$} \\
\cline { 2 - 4 } & $\begin{array}{c}\text { Corporations with > 300 } \\
\text { billion of owner's equity }\end{array}$ & $\begin{array}{c}\text { Corporations with 10-30 } \\
\text { billion of owner's equity }\end{array}$ & $\begin{array}{c}\text { Corporations with < 10 } \\
\text { billion of owner's equity }\end{array}$ \\
\hline 2015 & $81.25 \%$ & $81.11 \%$ & $90.63 \%$ \\
\hline 2016 & $77.44 \%$ & $88.26 \%$ & $92.14 \%$ \\
\hline 2017 & $70.98 \%$ & $84.85 \%$ & $93.81 \%$ \\
\hline 2018 & $65.63 \%$ & $82.17 \%$ & $90.66 \%$ \\
\hline 2019 & $63.80 \%$ & $81.14 \%$ & $94.14 \%$ \\
\hline Mean & $\mathbf{7 1 . 8 2 \%}$ & $\mathbf{8 3 . 5 0 \%}$ & $\mathbf{9 2 . 2 8 \%}$ \\
\hline
\end{tabular}

(Source: Financial statements of Military Construction Joint Stock Corporations 12and the authors' 
calculation)

Such asset investment structure is appropriate with operational features of construction field: investing more on current assets rather than on non-current ones. Because construction products are highly unique, different machines and devices are needed. An investment on all machines necessary for a project may lead to a failure in operating at full capacity. Moreover, constant changes in construction sites make moving machines difficult, time-consuming and costly. Therefore, it is appropriate for Military Construction Joint Stock Corporations not to focus too much on non-current assets.

\section{b) Secondly, the asset management is in line with the characteristics of each asset as well as the business features of the industry}

Short-term receivables and inventories account for the largest proportion (approximately over $87 \%$ ) in the current assets of Military Construction Joint Stock Corporations, the rest include cash and cash equivalents. Few Military Construction Joint Stock Corporations have short-term financial investment and other current assets.

Table 2. Proportion of short-term receivables and inventories in current assets of Military Construction Joint Stock Corporations during 2015-2019

\begin{tabular}{|c|r|r|r|}
\hline \multirow{2}{*}{ Year } & \multicolumn{3}{|c|}{$\begin{array}{c}\text { Proportion of short-term receivables and inventories in current assets of Military } \\
\text { Construction Joint Stock Corporations according to owner's equity scale (\%) }\end{array}$} \\
\cline { 2 - 4 } & $\begin{array}{c}\text { Corporations with }>300 \\
\text { billion of owner's equity }\end{array}$ & $\begin{array}{c}\text { Corporations with 10-30 } \\
\text { billion of owner's equity }\end{array}$ & $\begin{array}{c}\text { Corporations with <10 } \\
\text { billion of owner's equity }\end{array}$ \\
\hline 2015 & $84.89 \%$ & $90.82 \%$ & $93.22 \%$ \\
\hline 2016 & $87.51 \%$ & $85.15 \%$ & $95.68 \%$ \\
\hline 2017 & $86.18 \%$ & $89.75 \%$ & $95.50 \%$ \\
\hline 2018 & $87.54 \%$ & $92.84 \%$ & $88.44 \%$ \\
\hline 2019 & $90.25 \%$ & $91.48 \%$ & $90.21 \%$ \\
\hline Mean & $\mathbf{8 7 . 2 7 \%}$ & $\mathbf{9 0 . 0 1 \%}$ & $\mathbf{9 2 . 6 1 \%}$ \\
\hline
\end{tabular}

(Source: Financial statements of Military Construction Joint Stock Corporations 12 and the authors' calculation)

In current asset management, the focus on receivables and inventories is appropriate with operational characteristics of Military Construction Joint Stock Corporations.

Regarding account receivables, because the make to order happens in a long period of time and products have great value while payments are only carried out after handing over the projects or work items, debts are often incurred between owners and construction enterprises. Thus, accounts receivable comprises a high proportion in total assets of Military Construction Joint Stock Corporations. Some businesses have managed quite well by paying attention to selecting investors before participating in the bidding as well as taking timely measures to urge and collect account receivables.

Inventories make up around 20-30\% of the current assets of Military Construction Joint Stock Corporations. Production costs incurring in work in progress, which are construction products that have not been completed or inspected, handed over to owners, accounts for the largest proportion (over 90\%) while materials and tools represent about $10 \%$ of inventories (Table 3).

Because of the characteristics of construction field, production sites of Military Construction Joint Stock Corporations change according to geographical location of each project, thus, storing a large number of materials in one place will make it costly to impart them to another location. In fact, materials are often gathered at construction sites, stored in camps or outdoors, which helps reduce significantly the rent for warehouse. A lot of suppliers 
of construction materials participate in the market with competitive price and abundant supply, thus, satisfy the demands from military construction enterprises quickly and easily. As a result, materials are only purchased according to construction progress, making up a small proportion in the inventories of Military Construction Joint Stock Corporations.

Table 3. Inventory structure on December 31, 2019 of some Military Construction Joint Stock Corporations

\begin{tabular}{|c|c|c|c|c|c|c|}
\hline \multirow{3}{*}{ No. } & \multirow{3}{*}{$\begin{array}{c}\text { Name of construction } \\
\text { enterprises }\end{array}$} & \multirow{2}{*}{$\begin{array}{l}\text { Inventory } \\
\text { (Billion } \\
\text { dong) }\end{array}$} & \multicolumn{2}{|c|}{ Including } & \multicolumn{2}{|c|}{$\begin{array}{l}\text { Proportion in } \\
\text { inventory (\%) }\end{array}$} \\
\hline & & & $\begin{array}{l}\text { Materials } \\
\text { and tools }\end{array}$ & $\begin{array}{l}\text { Work in } \\
\text { progress }\end{array}$ & $\begin{array}{l}\text { Materials } \\
\text { and tools }\end{array}$ & $\begin{array}{l}\text { Work in } \\
\text { progress }\end{array}$ \\
\hline & & (1) & (2) & (3) & $(2) /(1)$ & $(3) /(1)$ \\
\hline 1 & 36 Corporation - JSC & 1244 & 98 & 1147 & $7.84 \%$ & $92.16 \%$ \\
\hline 2 & $\begin{array}{l}\text { Van Tuong Investment } \\
\text { and Construction Joint } \\
\text { Stock Company }\end{array}$ & 179 & 10 & 169 & $5.34 \%$ & $94.66 \%$ \\
\hline 3 & $\begin{array}{lr}\text { Truong } & \text { An } \\
\text { Development } & \text { and } \\
\text { Investment } & \\
\text { Construction } & \text { Joint } \\
\text { Stock Company } & \\
\end{array}$ & 90 & 1 & 89 & $1.66 \%$ & $98.34 \%$ \\
\hline 4 & \begin{tabular}{l}
\multicolumn{2}{l}{ Tay Ho Investment and } \\
Construction Joint \\
Stock Company
\end{tabular} & 26 & 1 & 25 & $4.08 \%$ & $95.92 \%$ \\
\hline 5 & $\begin{array}{l}389 \text { Construction Joint } \\
\text { Stock Company }\end{array}$ & 41 & 4 & 37 & $9.43 \%$ & $90.57 \%$ \\
\hline 6 & $\begin{array}{l}\text { Lam Son Construction } \\
\text { Joint Stock Company }\end{array}$ & 4 & 0 & 4 & $2.48 \%$ & $97.52 \%$ \\
\hline 7 & $\begin{array}{l}\text { Hung Vuong } \\
\text { Construction } \\
\text { Infrastructure } \\
\text { Development } \\
\text { Investment Joint Stock } \\
\text { Company } \\
\end{array}$ & 36 & 3 & 33 & $6.97 \%$ & $93.03 \%$ \\
\hline
\end{tabular}

(Source: Financial statements of Military Construction Joint Stock Corporations 12 and the authors' calculation)

Inventory management is a responsibility of the machinery and mechanically operated equipment management unit, department of Planning and Engineering. Due to the lack of fixed production site, Military Construction Joint Stock Corporations often choose material suppliers in place to reduce the transportation cost. Based on the estimated needs for materials of each project, managers of materials and mechanically operated equipment recommend potential suppliers.

Currently, Military Construction Joint Stock Corporations maintain low reserves, purchase materials based on construction progress, which is similar to the JIT (Just in time) model instead of the EOQ (Economic Order Quantity) one. This is a way to ensure the economic efficiency of Military Construction Joint Stock Corporations with specific characteristics of construction business.

\section{c) Thirdly, Military Construction Joint Stock Corporations have pretty stable short- term solvency}

An enterprise's short-term solvency can be evaluated based on: (i) Current ratio (current assets/ current liabilities) and (ii) Quick ratio (Current assets - Inventory/Current liabilities). 
These ratios were calculated and demonstrated in Table 4.

Table 4. Short-term solvency of Military Construction Joint Stock Corporations during 2015-2019

\begin{tabular}{|c|c|r|r|r|r|r|}
\hline \multirow{2}{*}{ Ratio } & $\begin{array}{c}\text { Enterprises' } \\
\text { owner' equity }\end{array}$ & $\begin{array}{c}\text { Year } \\
\mathbf{2 0 1 6}\end{array}$ & $\begin{array}{c}\text { Year } \\
\mathbf{2 0 1 7}\end{array}$ & $\begin{array}{c}\text { Year } \\
\mathbf{2 0 1 8}\end{array}$ & $\begin{array}{c}\text { Year } \\
\mathbf{2 0 1 9}\end{array}$ & Average \\
\hline \multirow{3}{*}{ Current ratio } & $>300$ billion & 1.30 & 1.00 & 1.17 & 1.13 & $\mathbf{1 . 1 5}$ \\
\cline { 2 - 7 } & $10-300$ billion & 1.10 & 1.11 & 1.11 & 1.10 & $\mathbf{1 . 0 9}$ \\
\cline { 2 - 7 } & $<10$ billion & 1.01 & 1.04 & 1.14 & 1.14 & $\mathbf{1 . 0 9}$ \\
\hline \multirow{3}{*}{ Quick ratio } & $>300$ billion & 1.03 & 0.69 & 0.63 & 0.70 & $\mathbf{0 . 7 6}$ \\
\cline { 2 - 7 } & $10-300$ billion & 0.72 & 0.68 & 0.76 & 0.79 & $\mathbf{0 . 7 4}$ \\
\cline { 2 - 7 } & $<10$ billion & 0.69 & 0.74 & 0.77 & 0.94 & $\mathbf{0 . 7 9}$ \\
\hline
\end{tabular}

(Source: Financial statements of Military Construction Joint Stock Corporations 12 and authors' calculation)

Table 4 shows that Military Construction Joint Stock Corporations have pretty good current ratio (with an average over 1.09). The quick ratio with an average of 0.7 shows that enterprises' solvency does not depend much on inventory. They are able to solve up to over $70 \%$ of current liabilities.

In general, Military Construction Joint Stock Corporations have enough current assets to solve current liabilities.

This result is achieved thanks to their financial management in line with the characteristics of construction enterprises and market in Vietnam. Also, they operate under tight supervision of the State and Ministry of Defense and maintain monthly, quarterly and yearly reports, resulting in stable financial management.

Despite a number of achievements, Military Construction Joint Stock Corporations still confront some problems in current asset management.

\subsection{Problems in current asset management and causes}

a) Firstly, although investments mainly on current assets are suitable with construction activities, Military Construction Joint Stock Corporations face potential liquidity risks and impacts on their business activities

Figure 1 describes the ratio of current liabilities to current assets of Military Construction Joint Stock Corporations during 2015-2019.

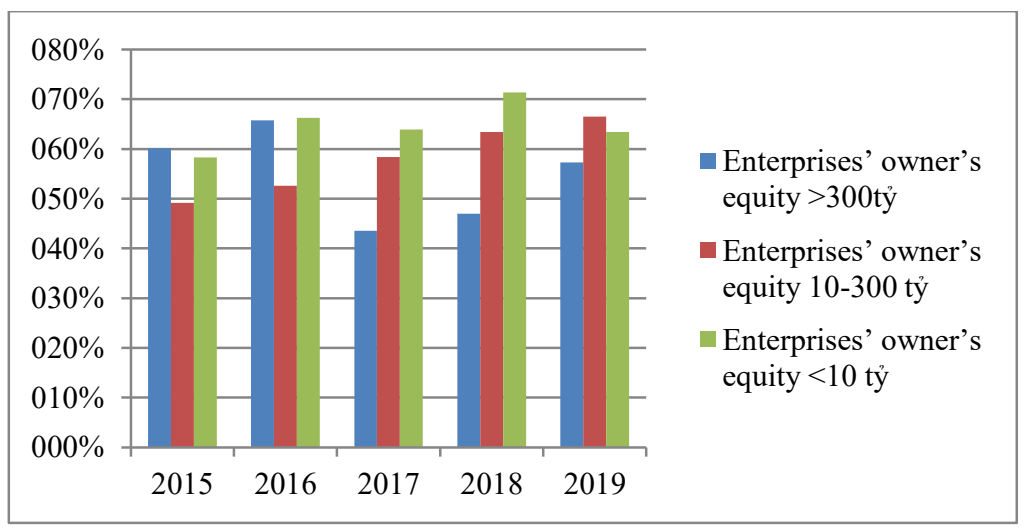

Fig. 1. The ratio of current liabilities to current assets of Military Construction Joint Stock Corporations during 2015-2019. 
(Source: Financial statements of Military Construction Joint Stock Corporations 12and authors' calculation)

According to Figure 1, during 2015-2019, Military Construction Joint Stock Corporations always had high current ratio, especially those with less than 10 billion dong of owner's equity (over 70\% of the total current assets in 2018).

Large investments on account receivables exert great effects on Military Construction Joint Stock Corporations' solvency. Particularly when owners have difficulties in finance or payment documents, Military Construction Joint Stock Corporations will face financial obstacles due to large account receivables, seriously affecting their solvency.

\section{b) Secondly, corporations' management of account receivables is poor, negatively affecting their operation}

Besides those who had good management of account receivables, some enterprises failed to take owners of projects into careful consideration due to short-term benefits, thus, facing difficulties when implementing the contract. There were cases when owners delayed payments and construction enterprises struggled with capital to continue the project and reduce losses. Because of owners' late payments, construction enterprises had to deal with the lack of capital to purchase construction materials or machinery or delay in paying laborers. In many cases, construction enterprises had to get loans from banks with much higher interests than the average profit they earned from projects.

Table 5 shows that on average, the account receivable turnover is from over 1 and under 3 (which means the average collection period is about 7 months). In the context of such high current ratio, this period is quite long (despite the characteristics of construction enterprises). This poses many liquidity risks and delays the contract completion.

Table 5. Account receivable turnover of Military Construction Joint Stock Corporations during 20152019

\begin{tabular}{|c|c|c|c|c|c|}
\hline \multirow{2}{*}{$\begin{array}{l}\text { Owner's equity of } \\
\text { Military } \\
\text { Construction Joint } \\
\text { Stock Corporations }\end{array}$} & \multicolumn{5}{|c|}{ Yearly account receivable turnover } \\
\hline & Year 2016 & Year 2017 & Year 2018 & $\begin{array}{l}\text { Year } \\
2019\end{array}$ & Average \\
\hline$>300$ billion dong & 1.57 & 0.83 & 1.25 & 1.06 & 1.18 \\
\hline $10-300$ billion dong & 1.46 & 1.62 & 0.89 & 0.64 & 1.15 \\
\hline$<10$ billion dong & 2.77 & 2.38 & 1.52 & 2.59 & 2.31 \\
\hline
\end{tabular}

(Source: Financial statements of Military Construction Joint Stock Corporations 12 and authors' calculation)

\section{c) Thirdly, there are risks from maintaining low reserves of supplies and materials in inventory management. The inventory management is ineffective.}

Although it is appropriate for Military Construction Joint Stock Corporations not to apply EOQ model but make progress-based purchases of materials in current construction context in Vietnam, there are many risks for them because of significant rises in prices of materials. Construction costs are greatly influenced by fluctuations in prices of materials. Remarkable rises in construction materials will quickly affect business activities and increase the costs of signed long-term contracts.

Table 6 shows that inventory turnover of Military Construction Joint Stock Corporations tends to decrease year by year. For Joint Stock Companies with Owner's equity over 300 billion dong, the average of 2.35 cycles per year, equivalent to 135 days/round or 5 months/round. It proves that inventories (which is mainly unfinished construction products) 
is not stagnant for too long to help improve the management efficiency of enterprises. With the operating characteristics of the construction enterprises, the production process takes many years and is divided into different categories, such inventory turnover is acceptable, helping to improve the efficiency of using assets of enterprises. However, in Joint Stock Companies with Owner's equity between 10 billion dong and 300 billion dong, the inventory turnover is lower, the average of 1.89 cycles per year, equivalent to 190 days/round or 6.5 months/round.

The inventory turnover of the group of joint stock companies with equity size of less than 10 billion dong is rather higher ( 7.83 rounds in a year). This does not show that management in these companies is more effectively than others. A closer look at the financial statements of the 3 joint stock companies with equity scale of less than 10 billion dong shows that the enterprises have low revenue (less than 100 billion dong/ year) and have very low profits (some years have no profits), which in turn leads to high cost of goods sold and high inventory turnover.

Table 6. Inventory turnover of Military Construction Joint Stock Corporations during 2015-2019

\begin{tabular}{|c|c|c|c|c|r|}
\hline \multirow{2}{*}{$\begin{array}{c}\text { Owner's equity of Military } \\
\text { Construction Joint Stock } \\
\text { Corporations }\end{array}$} & \multicolumn{5}{|c|}{ Yearly inventory turnover } \\
\cline { 2 - 7 } & $\begin{array}{c}\text { Year } \\
\mathbf{2 0 1 6}\end{array}$ & $\begin{array}{c}\text { Year } \\
\mathbf{2 0 1 7}\end{array}$ & $\begin{array}{c}\text { Year } \\
\mathbf{2 0 1 8}\end{array}$ & $\begin{array}{c}\text { Year } \\
\mathbf{2 0 1 9}\end{array}$ & \multirow{2}{*}{ Mean } \\
\hline$>300$ billion dong & 4.16 & 1.51 & 1.75 & 1.96 & $\mathbf{2 . 3 5}$ \\
\hline $10-300$ billion dong & 2.11 & 2.57 & 1.56 & 1.34 & $\mathbf{1 . 8 9}$ \\
\hline$<10$ billion dong & 8.36 & 8.33 & 5.22 & 9.42 & $\mathbf{7 . 8 3}$ \\
\hline
\end{tabular}

(Source: Financial statements of Military Construction Joint Stock Corporations 12 and the authors' calculation)

\section{d) Fourthly, the quick ratio is low}

The ability to make immediate payments can be evaluated based on "Quick ratio" (Cash/Current liabilities), which is demonstrated in Table 2.7.

Table 2.7. Quick ratio of Military Construction Joint Stock Corporations during 2015-2019

\begin{tabular}{|c|c|c|c|c|c|c|}
\hline \multirow{2}{*}{$\begin{array}{c}\text { Owner's equity of Military } \\
\text { Construction Joint Stock } \\
\text { Corporations }\end{array}$} & \multicolumn{6}{|c|}{$\begin{array}{l}\text { Yearly quick ratio of Military Construction Joint Stock } \\
\text { Corporations }\end{array}$} \\
\hline & $\begin{array}{l}\text { Year } \\
2015\end{array}$ & $\begin{array}{l}\text { Year } \\
2016\end{array}$ & $\begin{array}{l}\text { Year } \\
2017\end{array}$ & $\begin{array}{l}\text { Year } \\
2018\end{array}$ & $\begin{array}{l}\text { Year } \\
2019\end{array}$ & Average \\
\hline$>300$ & 0.17 & 0.14 & 0.09 & 0.08 & 0.08 & 0.11 \\
\hline $10-300 \mathrm{~b}$ & 0.08 & 0.15 & 0.08 & 0.05 & 0.07 & 0.09 \\
\hline$<10$ billion dong & 0.05 & 0.03 & 0.03 & 0.14 & 0.08 & 0.07 \\
\hline
\end{tabular}

(Source: Financial statements of Military Construction Joint Stock Corporations 12and authors' calculation)

According to Table 7, Military Construction Joint Stock Corporations have low ability to make immediate payment (with an average of 0.14 ). This means if they do not collect enough receivables, they can only pay $14 \%$ of the total liabilities with cash. Therefore, their liquidity is threatened if owners delay their payments.

\section{e) Fifthly, there are many limitations in cash flow management}

In order to meet the demand for liquidity, Military Construction Joint Stock Corporations invest a certain amount in cash. Daily transactions, salary payment, prepayment of some supplies, payment for machinery rent, ... take up a small proportion of cash uses (about 10- 
$15 \%$ of current assets) but they are all difficult to delay.

According to the authors' survey, none of the Military Construction Joint Stock Corporations apply optimization models for budget planning. There is no specific target for optimal level of cash balance. Normally, because enterprises' regular expenditure often exceeds their revenue, managers mainly focus on regulating the cash flow to ensure the minimum budget. The minimum cash balance is determined by enterprises to ensure shortterm solvency based on their expenditure plan, managerial experiences and reference to previous years. The budget deficit is common in businesses especially during last months of the year, putting pressure on managers to regulate the cash flow.

These limitations are caused by:

- Objective reasons stemming from the operational characteristics of Military Construction Joint Stock Corporations and construction industry in Vietnam. They force enterprises to maintain high current ratios and account receivable ratio, which increases liquidity risks.

- Status of construction market in Vietnam. In order to increase the efficiency of production and business, military construction enterprises purchase materials according to the construction progress, reduce the reserves of materials. However, this is increases the risks of material price fluctuations for long-term construction contracts.

- Financial analysis and planning has not come into focus. Currently, Military Construction Joint Stock Corporations carry out financial analysis according to bank loan requirements or the need for information to provide the year-end review. The financial analysis has not been carried out regularly, methodically and scientifically. Many military construction enterprises produce procedural financial plans to report to senior levels. Most of them only make short-term financial plans instead of strategic long-term ones. They only set plans based on annual situation without any methodical analysis and forecast.

- Administrators and financial managers of Military Construction Joint Stock Corporations have limited awareness and qualifications. They have not been aware of the importance of financial management in the enterprises' operational activities, the ultimate goal of financial analysis, which is to optimize the values of business owners. Besides, most of financial managers of Military Construction Joint Stock Corporations have yet to meet the requirements. They have great construction expertise, but lack thorough knowledge of financial management. The finance and accounting department staff mainly has accounting major and lacks qualifications in finance and financial management. Therefore, most of financial management activities are carried out according to habits and guidance from senior levels without any appropriate changes.

\section{Conclusions}

With an aim to enhance current asset management activities in particular and financial management in general in Military Construction Joint Stock Corporations, the authors come up with some following recommendations:

Firstly, it is important for enterprises to pay much attention to financial planning and analysis. There is a need to consider financial planning a vital task that requires carefulness. Regular and scientific financial analyses should be carried out using both integrated methods (for example, Dupoint 5 or econometric models 13) and traditional analytical ones.

Secondly, in current asset management, it is important to pay attention to account receivable management, ensure enterprises' ability to pay by: selecting investors, checking the legality of the project, checking project funding, negotiating payment methods when participating in bidding and measures to ensure ability to pay and monitor debt recovery.

Thirdly, there is a need to boost technological investments for the purposes of business administration, including financial management. In the context of industrialization era with 
the industrial revolution 4.0, information technology has played an undeniably significant role in people's life and work. The application of information technology in administration of enterprises from human resource to production is one of the hottest trends nowadays. Therefore, to improve the effectiveness of business administration in general and financial management in particular 14, military construction enterprises need to have strategies to invest in information technology.

Fourthly, it is crucial to improve financial management structure and financial managers' capacity. Accordingly, military construction enterprises need to separate accounting unit from financial one6, appoint a finance director with appropriate qualifications and expertise, learn from advanced financial management models worldwide 15 . Besides, there is a need to apply some measures to recruit candidates majoring in financial management or provide current employees with training.

Fifthly, it is vital to be fully aware of State and Ministerial policies regarding restructuring military construction enterprises so that the board of management can make appropriate decisions.

\section{References}

1. National Assembly, Resolution No. 24/2016/QH14 dated November 08, 2016 on the economic restructuring plan $2016-2020$.

2. Ministry of Defense, Circular No. 31/2008/TT-BQP dated March 17, 2008 on instructing enterprises with $100 \%$ state capital in the Army to become joint stock companies.

3. Ministry of Defense, Circular No. 56/2013 / TT-BQP dated May 2, 2013 on guiding the transformation of $100 \%$ state-owned enterprises in the Army into joint stock companies.

4. Ministry of Defense, Circular No. 155/2019 / TT-BQP dated October 15, 2019 on guiding the transfer of state-owned enterprises and one-member limited liability companies with $100 \%$ charter capital invested by state-owned enterprises Ministry of Defense became a joint stock company.

5. Eugene F. Brigham, Joel F. Houston, Financial Management (Cengage Learning Publishing, Singapore, 2009).

6. Chandra, Prasanna, Financial management (Tata McGraw-Hill Education, 2011).

7. Luu Thi Thu Ha, Solutions to restructure financial activities of Vietnam National Coal and Mineral Group (Doctoral Dissertation, Academy of Finance, Hanoi 2015).

8. Pham Thi Van Huyen, Financial management at listed companies in construction industry (Doctoral Dissertation, 2017).

9. Prime Minister, Decision No. 929/QD-TTg dated July 17, 2012 on the approval of the project "Restructuring state-owned enterprises with a focus on economic corporations, state-owned corporations during 2011 - 2015".

10. Prime Minister, Official Letter No. 1604/TTg-ĐMDN dated 08/10/2013 on the approval of the Scheme on organizing and innovating $100 \%$ foreign-owned enterprises under the Ministry of Defense.

11. Central Military Commission Standing Committee, Directive 430-CT/CMC dated June 12, 2015 on promoting innovation, arrangement and development of Military enterprises.

12. Financial statements of Military Construction Joint Stock Corporations from 20152019.

13. Engle, Robert, American Economic Review 94 (3), 405-420 (2004). 
14. N. Shin, European Journal of Information Systems 10 (4), 227-236 (2001)

15. Baxter, Jane, and Wai Fong Chua, Management Accounting Research 19 (3), 212-230 (2008) 